\title{
EFFECT OF VARYING LEVELS OF DIETARY VITAMIN C (ASCORBIC ACID) ON GROWTH, SURVIVAL AND HEMATOLOGY OF JUVENILE TILAPIA, Oreochromis karongae (TREWAVAS 1941) REARED IN AQUARIA
}

\author{
NSONGA, A.R.; KANG'OMBE, J.; MFITILODZE, W.; SOKO, C.K. \& MTETHIWA, A.H. \\ Department of Aquaculture and Fisheries Science, University of Malawi, Bunda College of \\ Agriculture, P.O BOX 219, Lilongwe, Malawi. E-mail: jeremiah_kangombe@yahoo.com
}

\begin{abstract}
Nsonga, A.R.; Kang'ombe, J.; Mfitilodze, W.; Soko, C.K. \& Mtethiwa, A.H. 2009. Effect of varying levels of dietary vitamin $\mathbf{C}$ (ascorbic acid) on growth, survival and hematology of juvenile tilapia, Oreochromis karongae (Trewavas 1941) reared in aquaria. Braz. J. Aquat. Sci. Technol. 13(2):17-23. ISSN 1808-7035. Vitamin $\mathrm{C}$ (ascorbic acid) requirement of juvenile Oreochromis karongae was studied by incorporating varying levels of ascorbyl-2-polyphosphate in a 40\% crude protein diet to obtain 0, 20, 40, 60 and $80 \mathrm{mg}$ ascorbic acid equivalent kg-1 diet. Juvenile fish of $3.7 \mathrm{~g} \pm 0.02 \mathrm{~g}$ initial body weight were used for the study. After 84 days of the experiment, the fish fed AAsupplemented diets had significantly $(P<0.05)$ higher specific growth rate protein conversion efficiency and protein efficiency ratio; and significantly $(P<0.05)$ better feed conversion ratios than non supplemented fish. Fish fed non supplemented diet recorded a $33 \%$ rate of mortality, where as those fed with a diet supplemented with $60 \mathrm{mg}$ ascorbic acid $\mathrm{kg}^{-1}$ had mortality as low as $4.4 \%$. Hematological indices showed a significant increase $(P<0.05)$ with dietary AA level. Diet containing $60 \mathrm{mg} \mathrm{kg}^{-1}$ of AA showed the maximum growth performance, while the broken line model gave 51 $\mathrm{mg}$ ascorbic acid $\mathrm{kg}^{-1}$ diet as the optimal level required by juvenile $O$. karongae. Our data show that ascorbic acid is essential for $O$. karongae growth performance.
\end{abstract}

Keywords: Clinical deficiency, Mortality, Conversion efficiency, Supplementation, Nutritional quality.

\section{INTRODUCTION}

Vitamin C (ascorbic acid) is an essential nutrient in aqua-feeds, and is an indispensable nutrient required to maintain physiological processes such as normal growth, immunity and reproduction of different animals including fishes (Tolbert, 1979). Ascorbic acid is watersoluble and is essential for several metabolic functions including the antioxidant system. Most fish, including tilapia, are not capable of vitamin C biosynthesis (Chatterjee, 1973) due to the absence of the enzyme Lgulonolactone oxidase, which is responsible for synthesis of ascorbic acid (Wilson, 1973). L-ascorbic acid is extremely labile and the rate of degradation is a function of storage time, with the effect of temperature, oxygen, $\mathrm{pH}$ and light. Recent studies indicate that ascorbic acid derivatives that include sulfate and phosphates are more resistant to oxidation and retain ascorbic acid activity for fish (Abdelghany, 1996).

Ascorbic acid requirements of some tilapia species have been investigated. Stickney et al. (1984), reported the fortification of $50 \mathrm{mg}$ of ascorbic acid equivalent $\mathrm{kg}^{-1}$ diet as the level that allows for maximum weight gain and absence of deficiency signs in blue tilapia (Oreochromis aureus). A diet of $79 \mathrm{mg}$ ascorbic acid $\mathrm{kg}^{-1}$ diet was found to be the requirement level for maximum weight gain of hybrid tilapia (Oreochromis niloticus $x$ Oreochromis aureus)(Shiau \& Jan, 1992).

The ascorbic acid requirement varies among fish species, but intraspecies differences such as fish strain, size and age also affect the dietary requirement. The amount of ascorbic acid that must be added to the diet for normal function is also dependent on the form of the vitamin that is added to the diet (Lim \& Webster, 2001).

In Malawi, nutritional studies are still in their infancy (Kang'ombe, 2004). This is the first attempt to determine the dietary ascorbic acid requirement of $O$. karongae. Oreochromis karongae, was recently isolated from the wild for aquaculture in Malawi and is farmed by both small holder and commercial farmers (Msiska \& Costa-Pierce, 1999). Although there is general information on Vitamin $\mathrm{C}$ requirement for tilapia, specific data on the effects of vitamin $\mathrm{C}$ on growth, survival and hematology of $O$. karongae are scarce. The present study therefore, attempted to determine the quantitative dietary requirement of ascorbic acid and its effect on growth, survival and hematology of $O$. karongae by using L-Ascorbyl-2-polyphosphate which is a more stable form of ascorbic acid. 


\section{MATERIALS AND METHODS}

\section{Experimental set up}

An indoor research trial was conducted in the wet laboratory of Bunda College of Agriculture, University of Malawi, over a period of 84 days (July to September 2006). Juvenile $O$. karongae $(3.7 \mathrm{~g} \pm 0.02 \mathrm{~g})$ were collected from National Aquaculture Centre, Domasi. To eliminate possible external parasites, fish were treated in sodium chloride bath of $2 \mathrm{mg} \mathrm{L}^{-1}$ every two days during two weeks of acclimatization. During acclimatization the fish were offered a maintenance diet containing $25 \%$ protein, twice a day. The experimental tanks were filled to the brim with well water. Continuous aeration was provided with the use of pressure pumps that maintained oxygen levels above $5.0 \mathrm{mg} \mathrm{L}^{-1}$ (Lawson, 1994).

\section{Experimental design}

Fifteen (15) tanks of $200 \mathrm{~L}$ were stocked with 35 fish each. Fish were conditioned for one week and fed a basal diet containing $25 \%$ crude protein. Five experimental diets with 5 varying levels of L-ascorbic acid (0 mg, $20 \mathrm{mg}, 40 \mathrm{mg}, 60 \mathrm{mg}$ and $80 \mathrm{mg} \mathrm{kg}^{-1}$ diet) with $99.9 \%$ purity (Kraft Chemical Company, Melrose Park, IL, US) containing $40 \%$ protein level (Table 1) were then assigned in triplicate to the experimental unit in a completely randomized design. The fish were hand fed to satiation twice daily at $6 \%$ of live body weight in pellet form.

\section{Sample Collection}

Growth of fish was monitored fortnightly with fish body weight $(\mathrm{g})$ and length $(\mathrm{cm})$ measured individually to make adjustment to feeding. Feed intake was taken into account for later calculations of feed conversion ration, protein conversion efficiency and protein efficiency ratio. Prior to sampling, fish were kept without feeding for 24 hours. Precaution was taken to minimize stress during the weighing by anaesthetizing the fish with FA 100 (Yanabe Yakuhin Co. Palo Alto, USA)(1.2g $\left.\mathrm{L}^{-1}\right)$. Every fortnight fish were euthanized for blood, liver and muscle analysis. The growth performance equations used are as indicated in the footnote of Table 2.

\section{Analytical Methods}

After measuring fish for growth, five fish per tank were then killed for liver and muscle ascorbate analysis using Indophenols Method (Seki 1990) and for hematological indices (differential, hematocrit and plasma protein) every fortnight. A hematocrit centrifugal machine at 12,000 rpm for 4 minutes and hematocrit reader were used to determine the packed cell volume of fish blood while the hand refractometer (Bellingham+Stanley, UK) was used for plasma protein

Table1 - Experimental diets with varying levels of vitamin $\mathrm{C}$ and their proximate composition used for feeding juveniles of $O$. karongae.

\begin{tabular}{|c|c|c|c|c|c|}
\hline \multirow[t]{2}{*}{ Ingredient } & \multicolumn{5}{|c|}{ Varying levels of Vitamin C } \\
\hline & $0 \mathrm{mg}$ & $20 \mathrm{mg}$ & $40 \mathrm{mg}$ & $60 \mathrm{mg}$ & $80 \mathrm{mg}$ \\
\hline Fishmeal & 38 & 38 & 38 & 38 & 38 \\
\hline Soybean(roasted) & 38 & 38 & 38 & 38 & 38 \\
\hline Maize bran & 8 & 8 & 8 & 8 & 8 \\
\hline Wheat bran & 2 & 2 & 2 & 2 & 2 \\
\hline Vegetable oil & 3 & 3 & 3 & 3 & 3 \\
\hline Rice bran & 8 & 7.989 & 7.967 & 7.934 & 7.89 \\
\hline $\begin{array}{l}\text { Vitamin premix(Vit } \\
\text { C free) }\end{array}$ & 1.5 & 1.5 & 1.5 & 1.5 & 1.5 \\
\hline Mineral premix & 1,5 & 1.5 & 1.5 & 1.5 & 1.5 \\
\hline Vitamin C $(\mathrm{mg} / \mathrm{kg})$ & 0 & 111 & 222 & 333 & 444 \\
\hline Total weight & 100 & 99.99 & 99.97 & 99.93 & 99.89 \\
\hline \multicolumn{6}{|c|}{ Proximate composition (\% Mean \pm SD) } \\
\hline Dry Matter & $87.2 \pm 1.4$ & $86.2 \pm 1.3$ & $87.2 \pm 1.3$ & $89.2 \pm 1.3$ & $88.2 \pm 1.3$ \\
\hline $\begin{array}{l}\text { Crude protein } \\
\text { Crude fibre }\end{array}$ & $\begin{array}{c}40.0 \pm 0.8 \\
2.8 \pm 0.4\end{array}$ & $\begin{array}{c}40.1 \pm 0.9 \\
2.8 \pm 0.4\end{array}$ & $\begin{array}{c}39.9 \pm 0.9 \\
2.7 \pm 0.4\end{array}$ & $\begin{array}{c}40.0 \pm 0.8 \\
2.8 \pm 0.4\end{array}$ & $\begin{array}{c}39.6 \pm 0.8 \\
2.8 \pm 0.4\end{array}$ \\
\hline Crude fat & $13.9 \pm 0.3$ & $13.8 \pm 0.3$ & $13.9 \pm 0.3$ & $13.8 \pm 0.3$ & $13.8 \pm 0.3$ \\
\hline Ash & $9.8 \pm 0.9$ & $10.2 \pm 0.9$ & $10.2 \pm 0.9$ & $9.9 \pm 0.9$ & $10.1 \pm 0.9$ \\
\hline $\begin{array}{l}\text { Nitrogen free } \\
\text { extract }\end{array}$ & $21.9 \pm 1.6$ & $22.1 \pm 1.5$ & $21.8 \pm 1.7$ & $22.0 \pm 1.5$ & $21.8 \pm 1.6$ \\
\hline $\begin{array}{l}\text { Gross energy } \\
(\mathrm{kJ} / \mathrm{g})\end{array}$ & $18.2 \pm 1.3$ & $18.2 \pm 1.3$ & $18.2 \pm 1.3$ & $18.2 \pm 1.3$ & $18.2 \pm 1.3$ \\
\hline $\begin{array}{l}\text { Ascorbic acid } \\
(\mathrm{mg} / \mathrm{kg})\end{array}$ & $<0.01$ & $19.5 \pm 1.2$ & $38.9 \pm 1.2$ & $58.9 \pm 1.2$ & $79.0 \pm 1.2$ \\
\hline \multicolumn{6}{|c|}{ 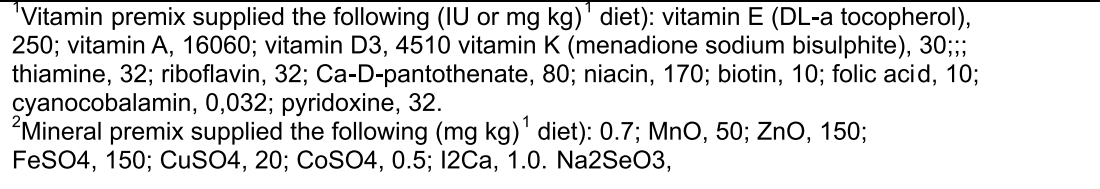 } \\
\hline
\end{tabular}


Braz. J. Aquat. Sci. Technol., 2009, 13(2):17-23.

Table 2 - Effect of Vitamin C (ascorbic acid, AA) on final mean body weights, weight gain, weight gain/day, percentage weight gain, specific growth rate (SGR), feed conversion ratio (FCR), protein conversion efficiency (PCE), protein efficiency ratio (PER) of juveniles of $O$. karongae after 12 weeks of treatment (Means $\pm \mathrm{SE})^{1}$.

\begin{tabular}{|c|c|c|c|c|c|}
\hline \multirow{2}{*}{ Parameters } & \multicolumn{5}{|c|}{ Treatments } \\
\hline & $0 \mathrm{mg} \mathrm{AA} / \mathrm{kg}$ & $20 \mathrm{mg} \mathrm{AA} / \mathrm{kg}$ & $40 \mathrm{mg} \mathrm{AA} / \mathrm{kg}$ & $60 \mathrm{mg} \mathrm{AA} / \mathrm{kg}$ & $80 \mathrm{mg} \mathrm{AA} / \mathrm{kg}$ \\
\hline $\begin{array}{l}\text { Initial mean } \\
\text { weight (g/fish) }\end{array}$ & $3.75 \pm 0.01$ & $3.76 \pm 0.01$ & $3.76 \pm 0.01$ & $3.76 \pm 0.01$ & $3.76 \pm 0.06$ \\
\hline $\begin{array}{l}\text { Final mean } \\
\text { weight (g/fish) }\end{array}$ & $4.78 \pm 0.12^{\mathrm{a}}$ & $9.64 \pm 0.14^{b}$ & $9.92 \pm 0.15^{b}$ & $13.79 \pm 0.28^{c}$ & $12.35 \pm 0.19^{c}$ \\
\hline $\begin{array}{l}\text { Weight gain } \\
(\mathrm{g} / \mathrm{fish})^{2}\end{array}$ & $1.03 \pm 0.35^{\mathrm{a}}$ & $5.88 \pm 0.30^{b}$ & $6.16 \pm 0.32^{b}$ & $10.03 \pm 0.33^{d}$ & $8.59 \pm 0.31^{c}$ \\
\hline $\begin{array}{l}\text { Weight } \\
\text { gain/day } \\
(\text { g/fish) }\end{array}$ & $0.01 \pm 0.01^{\mathrm{a}}$ & $0.07 \pm 0.01^{b}$ & $0.07 \pm 0.01^{b}$ & $0.12 \pm 0.01^{d}$ & $0.08 \pm 0.01^{c}$ \\
\hline $\begin{array}{l}\text { Weight gain } \\
(\%)^{4}\end{array}$ & $27 \pm 1.08^{a}$ & $156 \pm 1.05^{b}$ & $163 \pm 1.03^{b}$ & $266 \pm 1.11^{c}$ & $228 \pm 1.02^{c}$ \\
\hline SGR $(\% / \text { day })^{5}$ & $0.32 \pm 0.53^{\mathrm{a}}$ & $1.15 \pm 0.06^{b}$ & $1.18 \pm 0.09^{b}$ & $1.58 \pm 0.15 c$ & $1.45 \pm 0.65^{c}$ \\
\hline $\mathrm{FCR}^{6}$ & $3.20 \pm 0.53^{c}$ & $2.36 \pm 1.10^{\mathrm{b}}$ & $2.42 \pm 1.09^{b}$ & $2.30 \pm 1.05^{\mathrm{a}}$ & $2.32 \pm 1.07^{\mathrm{a}}$ \\
\hline $\mathrm{PCE}^{7}$ & $2.32 \pm 1.07^{\mathrm{a}}$ & $22.28 \pm 1.06^{b}$ & $22.65 \pm 1.08^{b}$ & $28.18 \pm 1.07^{c}$ & $22.9 \pm 1.09^{b}$ \\
\hline $\mathrm{PER}^{8}$ & $0.03 \pm 0.03^{\mathrm{a}}$ & $0.15 \pm 0.06^{b}$ & $0.15 \pm 0.03^{b}$ & $0.25 \pm 0.04^{c}$ & $0.21 \pm 0.10^{c}$ \\
\hline
\end{tabular}

\footnotetext{
${ }^{1}$ Means in the same column with different superscripts are significantly different $(P<0.05)$. Data represent means of $30 \mathrm{fish} /$ diet.

${ }^{2}$ Weight gain $(\mathrm{g} / \mathrm{fish})=$ final mean weight- initial mean weight.

${ }^{3}$ Weight gain/day $=$ (final mean weight - initial mean weight $) /($ days $)$

${ }^{4}$ Weight gain $(\%)=($ final mean weight - initial mean weight $) /$ initial mean weight $x 100$.

${ }^{5}$ SGR: specific growth rate $(\% /$ day $)=100 \times[($ In final weight $(\mathrm{g})-$ In initial weight $(\mathrm{g})) /($ days $)]$.

${ }^{6} \mathrm{FCR}$ : feed conversion ratio $=$ Total dry food offered $(\mathrm{g}) /$ weight wet gain $(\mathrm{g}) .{ }^{7} \mathrm{PCE}(\%)=100$ (final

body protein- initial body protein/amount of protein consumed). ${ }^{8} \mathrm{PER}=$ wet biomass gain $(\mathrm{g}) /$

amount of protein consumed (g).
}

reading. Hemacytometer (Thoma's counting chamber) was used for total blood cell count which was delayed until week 12 to allow for enough blood to build up since the fish used in the experiment were small. Observations for clinical signs on fish continued throughout the experimental period. Water in tanks was changed $50 \%$ every two days and complete clean up of tanks was done every fortnight. Water quality was monitored using Horiba water checker (Horiba Ltd, Kyoto, Japan).

\section{Water quality monitoring}

Water quality parameters remained in acceptable ranges during the twelve week experimental period and showed no significant differences $(P>0.05)$ across treatment diets. Temperature ranged between $21.8^{\circ} \mathrm{C} \pm$ 0.05 to $22.3 \pm 0.01$. Dissolved oxygen concentration averaged $6.5 \mathrm{mg} \mathrm{L}^{-1}$. The $\mathrm{pH}$ values ranged from $7.53 \pm$ 0.05 in treatment $0 \mathrm{mg}$ ascorbic acid kg-1 to $7.56 \pm 0.04$ in treatment $80 \mathrm{mg}$ ascorbic acid $\mathrm{kg}^{-1}$ diet. Ammonia averaged $0.16 \pm 0.3 \mathrm{mg} \mathrm{L}^{-1}$ and means were not significantly different $(P>0.05)$.

\section{Statistical Analyses}

All data were analysed using SPSS 12.0 software for Microsoft Windows (SPSS Inc., 2003). A One-way Analysis of variance was implemented and differences among the means were separated according to Duncan's multiple range tests at $5 \%$ (á) level. The Broken-line model analysis (Chou et al., 2001; Robbins et al. 2006) was used to estimate the optimum dietary ascorbic acid level requirement for juvenile $O$. karongae.

\section{RESULTS}

\section{Effect of vitamin $C$ on growth}

Fish fed diets without ascorbic acid had significantly lower $(P<0.05)$ weight gains than fish fed with ascorbic acid supplemented diets. Fish without ascorbic acid supplementation stopped growing at week 8 and began to lose weight. Fish fed ascorbic acid supplemented diets did not stop growing during the 12week feeding period and reached a significantly higher 
$(P<0.05)$ weight than did fish without dietary ascorbic acid. After 12 weeks of supplementation, $80 \mathrm{mg}$ ascorbic acid kg-1 diet gave mean weight of $12.35 \mathrm{~g}$ while $60 \mathrm{mg}$ ascorbic acid kg-1 diet gave mean weight of $13.79 \mathrm{~g}$. The $80 \mathrm{mg}$ ascorbic acid kg-1 diet did not promote additional weight increase for juvenile $O$. karongae.

During the 84 day period, non-supplemented fed fish gained only $27 \%$ of their initial weight whereas fish fed 20, 40, 60 and $80 \mathrm{mg} \mathrm{kg}^{-1}$ diet gained 156, 163, 266, and $228 \%$ of their initial weight, respectively. The diet containing $60 \mathrm{mg} \mathrm{kg}^{-1}$ produced highest weight gains (Table 2).

After 12 weeks, the specific growth rate, feed conversion ratio, protein conversion ratio and protein efficiency ratio were significantly lower $(P<0.05)$ in fish without ascorbic acid supplementation than those fed ascorbic acid supplemented diets (Table 2).

\section{Effect of vitamin C on hematology, ascorbate levels in liver and muscle}

Hematological values increased significantly $(P<0.05)$ with dietary ascorbic acid level. Diet without ascorbic acid supplementation showed the lowest values while diet $60 \mathrm{mg}$ ascorbic acid kg-1 indicated the highest hematological activity (Table 3). The packed cell volume also referred to as hematocrit, protein plasma, white blood cells, and red blood cell counts all showed significant $(P<0.05)$ results with increase in values of ascorbic acid. The ascorbate levels in both liver and muscle increased in all treatments except in the $0 \mathrm{mg}$ $\mathrm{kg}^{-1}$ treatment (Table 4).

\section{Effect of vitamin $C$ on disease condition}

After week 12, fish without a supplemented diet showed clinical signs, such as hemorrhage in the eye and fin and also had eroded fins and appeared darker while fish with supplemented diet were all in good health condition.

\section{Effect of vitamin $C$ on condition factor and survival of} fish

Condition factor indicates the stoutness of fish, and a well nourished fish has a condition factor of not less than 1 . The initial condition factor varied between 1.55 and 1.56 while the final condition factors ranged from 1.46 to 1.72 (Table 5). Significant differences $(P<0.05)$ were recorded in survival of juvenile $O$. karongae across diets with non-supplemented fed fish recording least figures. Survival significantly increased from 66.67 to $95.56 \%$, with ascorbic acid level. When supplementation of ascorbic acid was equal to or more than $60 \mathrm{mg} \mathrm{kg}^{-1}$, the survival (93.34- 95.56\%) was significantly $(P<0.05)$ higher to that of the control group $(66.67 \%)$, and no significant differences in survival were observed among fish fed diets with 60 and $80 \mathrm{mg} \mathrm{kg}^{-1}$ of ascorbic acid (Table 5).

\section{Vitamin $C$ requirement for juvenile $O$. karongae}

Vitamin $\mathrm{C}$ requirement for juvenile $O$. karongae was estimated by fitting a broken line model to the weight data and was found to be $51 \mathrm{mg}$ ascorbic acid $\mathrm{kg}^{-1}$ diet (Figure 1).

Table 3 - Initial and final haematological parameters of $O$. karongae fed observed under varying levels of ascorbic acid diets during 12 weeks of treatments (Mean $\pm \mathrm{SE})^{1}$.

\begin{tabular}{|c|c|c|c|c|c|c|c|c|}
\hline \multirow[b]{2}{*}{$\begin{array}{l}\text { Diet } \\
\mathrm{AA} \\
\mathrm{mg} / \mathrm{kg}\end{array}$} & \multicolumn{8}{|c|}{ Haematological parameters } \\
\hline & \multicolumn{2}{|c|}{$\begin{array}{l}\text { Packed Cell } \\
\text { Volume } \\
\text { (g/100L) }\end{array}$} & \multicolumn{2}{|c|}{$\begin{array}{l}\text { Plasma Proteins } \\
\text { Counts } / \mathrm{mm}^{3}\end{array}$} & \multicolumn{2}{|c|}{$\begin{array}{l}\text { White Blood Cells } \\
\text { Count } / \mathrm{mm}^{3}\end{array}$} & \multicolumn{2}{|c|}{ Red Blood Cells (\%) } \\
\hline & Initial & Final & Initial & Final & Initial & Final & Initial & Final \\
\hline 0 & $12 \pm 1.04$ & $15 \pm 1.04^{a}$ & $1.5 \pm 1.14$ & $1.0 \pm 1.09^{a}$ & $\begin{array}{c}5.55 x \\
10^{4} \pm 1.03\end{array}$ & $\begin{array}{c}6.66 x \\
10^{4} \pm 1.43^{a}\end{array}$ & $\begin{array}{c}1.00 x \\
10^{6} \pm 1.04\end{array}$ & $\begin{array}{c}1.99 \times 10^{6} \pm \\
1.11^{\mathrm{a}}\end{array}$ \\
\hline 20 & $12 \pm 1.09$ & $29 \pm 1.07^{b}$ & $1.5 \pm 1.02$ & $2.8 \pm 1.11^{b}$ & $\begin{array}{c}5.55 x \\
10^{4} \pm 1.43\end{array}$ & $\begin{array}{c}6.96 x \\
10^{4} \pm 0.85^{b}\end{array}$ & $\begin{array}{c}1.00 x \\
10^{6} \pm 1.23\end{array}$ & $\begin{array}{c}2.05 x \\
10^{6} \pm 1.34^{b}\end{array}$ \\
\hline 40 & $12 \pm 1.04$ & $30 \pm 1.03^{b}$ & $1.5 \pm 1.02$ & $2.8 \pm 1.11^{b}$ & $\begin{array}{c}5.55 x \\
10^{4} \pm 1.19\end{array}$ & $\begin{array}{c}7.00 x \\
10^{4} \pm 0.49^{b}\end{array}$ & $\begin{array}{c}1.00 x \\
10^{6} \pm 1.13\end{array}$ & $\begin{array}{c}2.61 \times 10^{6} \pm \\
1.20^{b}\end{array}$ \\
\hline 60 & $12 \pm 1.05$ & $30 \pm 1.12^{b}$ & $1.5 \pm 1.01$ & $3.0 \pm 1.12^{b}$ & $\begin{array}{c}5.55 x \\
10^{4} \pm 1.07\end{array}$ & $\begin{array}{c}7.30 x \\
10^{4} \pm 1.49^{b}\end{array}$ & $\begin{array}{c}1.00 x \\
10^{6} \pm 1.20\end{array}$ & $\begin{array}{c}3.05 x \\
10^{6} \pm 1.19^{c}\end{array}$ \\
\hline 80 & $12 \pm 1.12$ & $30 \pm 1.09^{b}$ & $1.5 \pm 1.09$ & $3.0 \pm 1.22^{b}$ & $\begin{array}{c}5.55 \times \\
10^{4} \pm 1.06\end{array}$ & $\begin{array}{c}7.20 x \\
10^{4} \pm 1.65^{b}\end{array}$ & $\begin{array}{c}1.00 x \\
10^{6} \pm 1.01\end{array}$ & $\begin{array}{c}3.34 x \\
10^{6} \pm 1.41^{c}\end{array}$ \\
\hline
\end{tabular}

\footnotetext{
${ }^{1}$ Means in the same column sharing different superscripts are significantly different $(P<0.05)$.
} 
Table 4 - Initial and final ascorbate levels in liver and muscle of $O$. karongae fed with varying levels of ascorbic acid diets during 12 weeks of treatments $(n=3)$ (Mean \pm SE).

\begin{tabular}{lcccc} 
& \multicolumn{3}{c}{ Ascorbate levels $\left(\mu \mathrm{g} \mathrm{g}^{-1}\right.$ tissue $)$} \\
\hline $\begin{array}{l}\text { Diet AA } \\
\left(\mathrm{mg} \mathrm{k} \mathrm{g}^{-1}\right)\end{array}$ & \multicolumn{2}{c}{ Liver } & \multicolumn{2}{c}{ Muscle } \\
\hline & Initial & Final & Initial & Final \\
0 & $23.1 \pm 1.2$ & $5.1 \pm 0.9$ & $7.1 \pm 1.3$. & $1.8 \pm 0.1$ \\
20 & $23.2 \pm 1.4$ & $33.2 \pm 1.7$ & $7.1 \pm 1.7$ & $18.2 \pm 1.7$ \\
40 & $23.2 \pm 1.5$ & $45.1 \pm 1.3$ & $7.3 \pm 1.6$ & $18.6 \pm 1.6$ \\
60 & $23.4 \pm 1.2$ & $59.3 \pm 1.6$ & $7.1 \pm 1.8$ & $24.3 \pm 1.3$ \\
80 & $23.6 \pm 1 . .5$ & $75.4 \pm 1.2$ & $7.2 \pm 1.3$ & $27.1 \pm 1.5$ \\
\hline
\end{tabular}

\section{DISCUSSION}

The results of this study strongly indicate that vitamin $\mathrm{C}$ significantly affects the growth, survival and hematology of juvenile $O$. karongae. Growth is a function of both the nutritional quality and the rate of consumption, among other things (Stickney, 2000). In this research trial, a diet containing $51 \mathrm{mg}$ of ascorbic acid $\mathrm{kg}^{-1}$ diet was found to be the optimal dietary requirement for juvenile $O$. karongae while $60 \mathrm{mg}$ ascorbic acid $\mathrm{kg}^{-1}$ diet was found to be the requirement level for maximum growth and performance of $O$. karongae. The ascorbic acid requirement value by $O$. karongae attained in this experiment was higher than those reported for Oreochromis aureus between 10 and $25 \mathrm{mg}$ ascorbic acid who also examined juvenile hybrid tilapia, Oreochromis niloticus $x$ O. aureus (Shiau \& Hsu, 1999).

However, the requirement based on growth performance in this study was lower than that for Oreochromis spilurus (100-200 mg ascorbic acid kg-1 diet) (Al-Amoudi et al., 1992). The difference is probably related to fish species, size, the form of vitamin $C$ and experimental conditions in different studies (Lovell, 1989). The $60 \mathrm{mg}$ ascorbic acid kg-1 diet found as requirement level for maximum growth agrees with Li \& Lovell (1985) who demonstrated that fish raised from 3 to $19 \mathrm{~g}$ required $60 \mathrm{mg}$ ascorbic acid $\mathrm{kg}^{-1}$ diet for maximum weight gain. Weight gain increase with dietary level is considered by many nutritionists to be the most important and meaningful response in nutritional requirement studies (Stickney, 2000).

The diet without ascorbic acid supplementation decreased the specific growth rate $\left(0.32 \%\right.$ day $\left.^{-1}\right)$ of juvenile $O$. karongae and this is in accordance with studies conducted by Ai et al. (2004) who also observed declining specific growth rate with ascorbic acid deficient
Table 5 - Initial and final condition factor $(\mathrm{K})$, and Survival of $O$. karongae cultured in indoor tanks after 12 weeks of treatment $(\text { Mean } \pm \text { SE) })^{1}$.

\begin{tabular}{lccc}
\hline AA mg/diet & \multicolumn{3}{c}{ Parameters } \\
\hline & Initial Condition (K) & Final Condition (K) & Survival (\%) \\
0 & $1.56 \pm 0.02$ & $1.46 \pm 0.09^{\mathrm{a}}$ & $66.67 \pm 0.32^{\mathrm{a}}$ \\
20 & $1.55 \pm 0.03$ & $1.60 \pm 0.08^{\mathrm{b}}$ & $86.67 \pm 0.16^{\mathrm{b}}$ \\
40 & $1.55 \pm 0.04$ & $1.68 \pm 0.11^{\mathrm{b}}$ & $87.67 \pm 0.18^{\mathrm{b}}$ \\
60 & $1.55 \pm 0.01$ & $1.72 \pm 0.12^{\mathrm{b}}$ & $95.56 \pm 0.01^{\mathrm{C}}$ \\
80 & $1.56 \pm 0.10$ & $1.70 \pm 0.07^{\mathrm{b}}$ & $93.34 \pm 0.21^{\mathrm{c}}$ \\
\hline \multicolumn{4}{l}{ Values of different superscripts in a column are significantly different at $P<0.05}$.
\end{tabular}

diet for seabass (Scophthalmus maximus). Stickney (1994) reported that feed conversion factor values can actually be less than 1 in water systems where there is natural food. Goddard (1996) observed that poor or fluctuating feed conversion ratios may reflect problems with diets or feeding methods. In the present study, fish fed with non supplemented diet had poor food conversion ratio (4.2) while fish fed with the supplemented diet recorded 2.0-2.42 as feed conversion ratios.

Feed utilization in this study was also affected by the dietary level of ascorbic acid. Total amount of feed consumed increased with ascorbic acid level. Both protein conversion efficiency and protein efficiency ratio were much lower in fish fed with diet without ascorbic acid. This indicate lower protein utilization by the fish. Fracalossi et al. (1998) observed a similar trend in juvenile Oscars (Astronotus ocellatus) cichlids. The diet used in the present experiment had high protein content $\left(400 \mathrm{~g} \mathrm{~kg}^{-1}\right)$, which could have resulted in the fish consuming high levels of oxygen as consumption increases with protein in tilapia (Ross, 2000).

In this study, a number of other healthy related conditions were uncovered due to ascorbic acid deficiency. For instance, hematology of the fish was significantly affected by ascorbic acid. Fish without ascorbic acid supplementation showed lower values for hematocrit $(15 \%)$, total white blood cell $\left(6.66 \times 10^{4} / \mathrm{mm}^{3}\right)$, red blood cells $\left(1.99 \times 10^{6} / \mathrm{mm}^{3}\right)$ and plasma protein $\left(1.0 \mathrm{~g} 100 \mathrm{~L}^{-}\right.$ $\left.{ }^{1}\right)$. These negative trends compromised the healthy status of the fish that showed clinical signs such as fin erosion and broken back disease. Shiau \& Jan (1992) found similar results in hybrid tilapia without dietary ascorbic acid that showed lower hematocrit than fish receiving ascorbic acid supplementation. Shiau \& Jan (1992) reported that anemia is common in animals with ascorbic acid deficiency because there is reduction in the absorption and redistribution of iron and consequently a reduction in the synthesis of hemoglobin. Fracalossi et al. (1998) also reported signs of scurvy on Oscars (Astronotus ocellatus) such as reduced growth, impaired collagen formation and lordosis due to non supplementation of ascorbic acid. In this study, juvenile 
O. karongae not supplemented with ascorbic acid showed elevated levels of neutrophils. According to Roberts (1989), excess release of neutrophils into the blood of mammals and fish is a response to stress. Absence of ascorbic acid therefore may have induced a physiological stress on juvenile $O$. karongae.

There is a relationship between tissue ascorbate and the fish health (Halver, 1985). In the present study fish with non supplemented diets showed declining ascorbate levels in both the liver and the muscle. On the other hand, fish with supplemented diet showed increased levels of ascorbate. Ai et al. (2004) got similar results on Japanese seabass (Lateolabrax japonicus) and according to Lim \& Lovell (1978), requirement for tissue saturation is much higher than that for normal fish growth that could prevent deficiency signs. Therefore increased tissue ascorbate in $O$. karongae fed with supplemented diet of ascorbic acid had a positive effect on the health of the fish (Halver, 1985). A relatively low rate of survival $(60 \%)$ was observed in juvenile $O$. karongae fed with a non-supplemented diet of ascorbic acid. The significantly lower survival in fish fed with nonsupplemented diet can only be attributed to the physiological stress caused by dietary ascorbic acid deficiency and not due to water quality since all low water quality parameters were within the ranges known to be required by tilapia. The level of dissolved oxygen was above $5 \mathrm{mg} \mathrm{L}^{-1}$ in all treatments, which is ideal for warm water fishes (Buttner et al., 1993). The oxygen level was above 2.5 and $1 \mathrm{mg} \mathrm{L}^{-1}$ where $O$. niloticus showed signs of stress (decrease in activity accompanied by body coloration and erection of dorsal fin) in similar systems (Ross, 2000). The water $\mathrm{pH}$ of 7.5 across the treatments was within the limits for the growth of several species of tilapias (Boyd \& Tucker, 1998; Ross, 2000).

In conclusion, supplementation of $60 \mathrm{mg}$ ascorbic acid $\mathrm{kg}^{-1}$ in the diet significantly yielded the maximum fish performance in terms of weight gain and overall health condition in this nutrient dose-response experiment. We also conclude that $51 \mathrm{mg}$ ascorbic acid $\mathrm{kg}^{-1}$ in the diet is the optimal dietary requirement for $O$. karongae and must be fortified to pelleted diets in order to maximize ascorbic acid bioavailability to juvenile O. karongae.

\section{ACKNOWLEDGEMENTS}

The authors thank the Icelandic International Development Agency (ICEIDA) for financial support of experiments during the Master's studies of the first author. Special thanks should also go to the former Aquaculture Farm Manager, Late Mr. A.G. Matambo for tireless effort in the logistical arrangements of this research. We thank Mr. B. Lusangasi for daily fish care and Mr. E. Nyali for laboratory analyses. Thanks go to Bunda College of Agriculture for making facilities available for the research. Mr lain Elliot (Institute of Aquaculture, University of Stirling, UK) provided insightful comments to the manuscript.

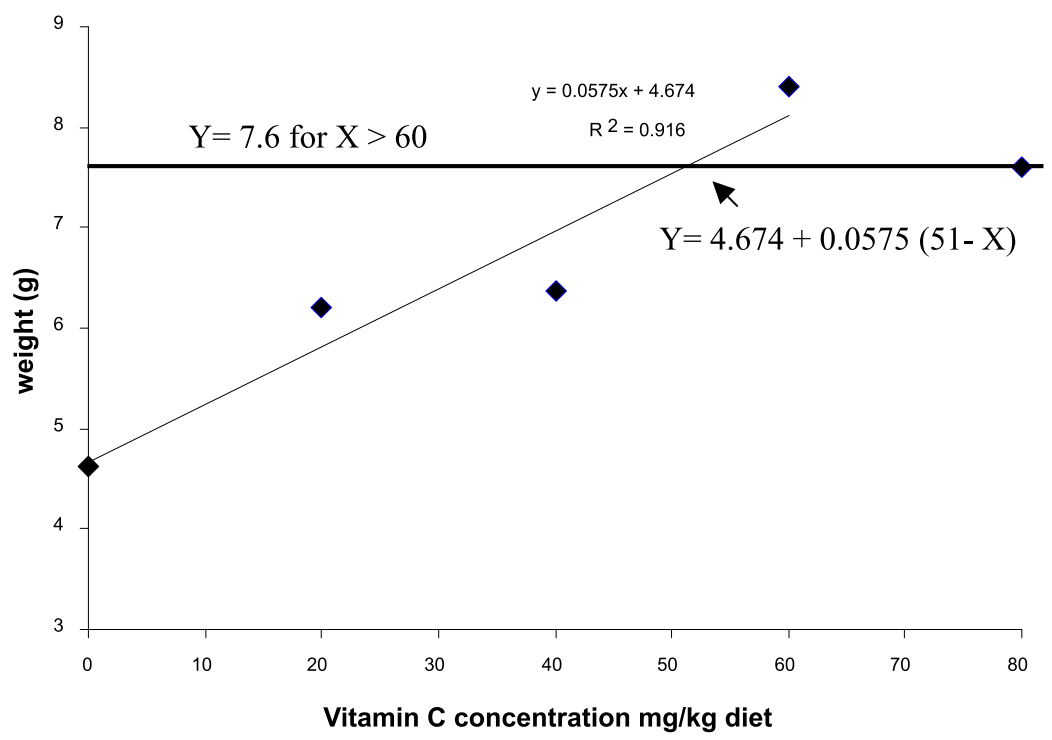

Figure 1 - Broken-Line model for the ascorbic acid requirement of juvenile O. karongae. Weight breakpoint is at $51 \mathrm{mg}$ ascorbic acid kg ${ }^{1}$ diet $(\mathrm{n}=3$ tanks). 


\section{REFERENCES}

Abdelghany, A. 1996. Growth response of Nile tilapia Oreochromis niloticus to dietary L-ascorbic acid, Lascorbyl-2-sulfate, and L-ascorbyl-2-polyphosphate. J. World Aquacult. Soc. 27: 449-445.

Ai, Q., Mai, K., Zhang, C., Xu, W., Duan, Q., Tan, B. \& Liufu, Z. 2004. Effects of dietary Vitamin $C$ on growth and immune response of Japanese seabass, Lateolabrax japonicus. The Key Laboratory of Mariculture, Ocean University of China, Qingdao 266003, P.R. China. Aquaculture. 62:1-12.

Al-amoudi, M.M., El-nakkadi \& El-nouman, B.M. 1992. Evaluation of optimum dietary requirement of vitamin $\mathrm{C}$ for the growth of Oreochromis spilurus fingerlings in water from the Red sea. Aquaculture. 105:165173.

Boyd, C.E. \& Tucker, C.S. 1998. Pond aquaculture water quality management. Kluwer Academic Publishers, Boston. 70p.

Buttner, J.K., R.W., Soderberg \& Terlizzi, D.E. 1993. An introduction to water chemistry in freshwater aquaculture. Northeastern Regional Aquaculture Center. NRAC Fact sheet No. 170. University of Massachusetts, Dartmouth, North Datmouth, Massachusetts, USA, 4p.

Caulton, M.S. 1982. Feeding, metabolism and growth of tilapias: some quantitative considerations. In: Pullin, R.S.V. \& Lowe-McConnell, R.H. (eds.) The biology and culture of tilapia. ICLARM Conference Proceedings 7. 157-180pp.

Chatterjee, I. B. 1973. Evolution and biosynthesis of ascorbic acid. Science. 182: 1271-1272

Chou, R L., Su, M.S and Chen, H.Y. 2001. Optimal dietary protein and lipid levels for juvenile cobia (Rachycentron canadum). Aquaculture. 193: 81-89

Fracalossi, D.M., Allen, M.E., Nichols, D. K. \& OftedaL, O.T. 1998. Oscars, Astronotus ocellatus, have a dietary requirement for Viatamin C. J. Nutr. 128:17451751.

Goddard, S. 1996. Feed management in intensive aquaculture. Chapman and Hall. New York, 194p.

Halver, J.E. 1985. Recent advances in vitamin nutrition and metabolism. In: Nutrition and feeding in fish. In: Cowey, C.B., A.M., Mackie \& Belleds, J.G. (eds.). Academic Press, New York. 415- 429pp.

Kang'ombe, J. 2004. Development of feeding protocols for Tilapia rendalli in Malawi reared in semi-intensive culture systems. Ph.D. Thesis, Biology Department. Memorial University of Newfoundland, Canada. 221p

Lawson, T.B. 1994. Fundamentals of aquaculture engineering, Chapman and hall, New York. 355p
Li, Y. \& Lovell R.T. 1985. Elevated levels of dietary ascorbic acid increase immune response in channel catfish. J. Nutr. 115:123-131.

Lim, C. \& Lovell R.T. 1978. Pathology of the vitamin C deficiency syndrome in channel catfish (Ictalurus punctatus). J. Nutr. 108: 1137-1146.

Lim, C. \& Webster C. D. 2001. Nutrition and fish health. The Haworth press, New York, U.S.A. 163p.

Lovell, R.T. 1989. Vitamin C (ascorbic acid). In: Nutrition and feeding of fish. pp. 54-60. An AVI Book, Van Nostrand Reinhold Publication.

Msiska O.V. \& Costa-Pierce B.A. 1999. Maturity and gonad changes in Oreochromis (Nyasalapia) karongae raised in fishponds in Malawi. J. Appl. Ichthyol. 15 (3): 97-103.

Roberts, R. J. 1989. The anatomy and physiology of teleosts. In: Fish pathology Bailliere Tindal, London. $27-30 \mathrm{pp}$.

Robbins, K.R., Saxton, A.M. and Southern, L.L. 2006. Estimation of nutrient requirements using brokenline regression analysis. J. Anim. Sci. 84: 155-165

Ross, L.G. 2000. Environmental physiology and energetics. In: Beveridge, M.C.M \& McAndrew, B..J. (eds.) Tilapia: Biology and exploitation pp.89-128. Kluwer Academic Publishers, London.

Seki, T. 1990. Food analysis manual. Jomo Kenyatta University, College of Agriculture and technology, Nairobi, Kenya. 49p.

Shiau, S.Y. \& Jan. F.L. 1992. Dietary ascorbic acid requirement of juvenile tilapia Oreochromis niloticus x Oreochromis aurea. B. Jpn. Soc. Sci. Fish. 58: 671-675.

Shiau, S.Y. \& Hsu, T.S. 1999. Quantification of vitamin $C$ requirement for juvenile hybrid tilapia, Oreochromis niloticus x Oreochromis aureus, with L-ascorbyl-2monophosphate- $\mathrm{Na}$ and L-ascorbyl-2monophosphate-Mg. Aquaculture. 114:1-18.

SPSS, 2003. SPSS Base 12.0 for Windows. SPSS Inc., Chicago, Illinois, USA

Stickney, R.R. 1994. Principles of aquaculture. John Wiley and Sons, Inc: New York. 502p.

Stickney, R.R. 2000. Encyclopedia of aquaculture. John Wiley and Sons, Inc: New York 960p.

Tolbert, B.M. 1979. Ascorbic acid metabolism and physiological function. Int. J. Vitam. Nutr. Res. 19: 127-142

Wilson, R.P. 1973. Absence of ascorbic acid synthesis in channel catfish, Ictalurus punctatus, and blue catfish, Ictalurus frucatus. Comp. Biochem. Phys. 46B: 635- 638. 